\title{
Peningkatan Layanan Jaringan Internet Menggunakan Teknik Load Balancing pada Balai Besar Pelatihan Kesehatan Ciloto
}

\author{
LILA SETIYANI
}

\author{
Program Studi Sistem Informasi \\ STMIK ROSMA Karawang \\ Jl. Raya Kertabumi No.62 Karawanga \\ Email: lila.setiyani@dosen.rosma.ac.id
}

\begin{abstract}
The need for greater Internet network usage, of course, need technology support as well as Internet network management that can provide data exchange speed service and without disconnected connection. The Great Hall of Health Training (BBPK) Ciloto has subscribed one of Telkom Internet service provider with ASTINET Dedicated products. In Internet usage using ASTINET Dedicated, BBPK Ciloto want to improve Internet network service by adding Internet service backup, to anticipate the occurrence of dropouts in ASTINET Dedicated service. For that, researchers will do internet network management on the router BBPK ciloto by combining ASTINET Dedicated service with Internet Backup service. To combine these services researchers use load balancing techniques. Besides merging this serves to build Internet backups, also used to divide the load that comes on the router related Internet service, so it is not centered on any of the Internet services. The methodology used in this research is the approach of PPDIOO, which is prepare, plan, design, Implement, operate (operate) and optimize (optimization). The results of this research are Internet network that uses two Internet inputs with one output with balanced load sharing.
\end{abstract}

Key words: Internet, internet networks, internet service provider (ISP), load balancing

\begin{abstract}
Abstrak. Kebutuhan akan penggunaan jaringan internet yang semakin besar, tentunya membutuhkan dukungan teknologi serta manajemen jaringan internet yang dapat menyediakan layanan kecepatan pertukaran data dan tanpa terputus koneksi. Balai Besar Pelatihan Kesehatan (BBPK) Ciloto telah berlangganan salah satu internet service provider telkom dengan produk ASTINET Dedicated. Dalam penggunaan internet menggunakan ASTINET Dedicated, BBPK Ciloto ingin meningkatkan layanan jaringan internet dengan menambahkan backup layanan internet, untuk mengantisipasi terjadinya putus koneksi pada layanan ASTINET Dedicated. Untuk itu peneliti akan melakukan manajemen jaringan internet pada router BBPK ciloto dengan menggabungkan layanan ASTINET Dedicated dengan layanan backup internet. Untuk mengkombinasi layanan tersebut peneliti menggunakan teknik load balancing. Selain penggabungan ini berfungsi untuk membangun backup internet, juga digunakan untuk membagi beban yang datang pada router terkait layanan internet, Sehingga tidak berpusat pada salah satu layanan internet. Metodologi yang digunakan pada penelitian ini adalah pendekatan PPDIOO yaitu prepare (persiapan), plan (perencanaan), Desain (desain), Implement(implementasi), operate(operate) dan optimize(optimasi). Hasil penelitian ini adalah jaringan internet yang menggunakan dua input internet dengan satu keluaran dengan pembagian beban yang seimbang.
\end{abstract}

Kata Kunci: Internet, jaringan internet, internet service provider (ISP), load balancing 


\section{PENDAHULUAN}

Peningkatan drastis penggunaan internet di seluruh dunia, mendorong institusi atau perusahaan untuk melakukan peningkatan layanan pendukung akses internet yaitu infrastruktur yang mumpuni.

Balai Besar Pelatihan Kesehatan (BBPK) Ciloto telah melakukan beberapa strategi untuk meningkatkan layanan internet di lembaganya dengan membangun infrastruktur jaringan internet serta berlanggan pada internet service provider (ISP) yang terpercaya yaitu telkom. Internet service provider merupakan perusahaan yang menyelengarakan jasa sambungan internet, baik secara domestik atau local maupun internasional sehingga pengguna dari sambungan yang disediakan ISP dapat terhubung ke jaringan internet global (IdCloudHost, ISP, 2017). BBPK Ciloto telah berlangganan produk telkom yaitu ASTINET dedicated dengan fasilitas 5 (lima) IP Public dan bandwith $30 \mathrm{Mbps}$ dedicated local international.

Semakin banyaknya proses bisnis yang didukung dengan menggunakan layanan internet ini mendorong BBPK Ciloto untuk meningkatkan layanan internet dengan membangun backup internet yang berfungsi sebagai pengganti jika terjadi masalah pada ASTINET dedicated dan juga berfungsi sebagai penyeimbang layanan ASTINET dedicated jika terjadi penggunaan akses internet yang melebihi bandwith $30 \mathrm{Mbps}$.

Dalam penelitian ini, peneliti melakukan setting configuration pada router BBPK Ciloto untuk menggabungkan dua layanan yaitu ASTINET dedicated dengan layanan backup internet. Untuk melakukan penggabungan layanan tersebut, peneliti menggunakan teknik load balancing yaitu suatu proses pendistribusian beban terhadap sebuah layanan yang ada pada sekumpulan server atau perangkat jaringan ketika ada permintaan dari pengguna, dengan membagi beban yang datang ke beberapa server sehingga tidak terpusat pada satu perangkat jaringan saja. Teknik load balancing ini menjamin reliabilitas layanan ketersediaan beban bandwoth dan kemampuan suatu jaringan (Muhammad Gustriana, 2016).

Teknik load balancing memiliki tiga metode yaitu static route with address list, equal cost multi path $i$ dan Nth. Namun pada penelitian ini, peneliti menggunakan metode static route with address list yaitu metode load balancing yang mengelompokkan suatu range IP address untuk dapat diatur melewati salah satu gateway dengan menggunakan static routing (Haris, 2013). Peneliti memilih metode ini karena kemudahan dalam membangi jaringan dengan topologi sederhana, dan tidak ada disconnection pada client yang disebabkan perpindahan getway karena load balancing. Dalam load balancing terdapat dua pilihan yang perlu dipertimbangkan ketika merancang solusi load balancing, yaitu menggunakan software load balancing atau menggunakan hardware load balancing. Pada penelitian ini peneliti memilih menggunakan hardware load balancing yaitu router mikrotik RB1100AH2X (IdCloudHost, 2015).

\section{METODE}

Dalam melakukan proses setting configuration untuk menggabungkan dua layanan internet dengan teknik load balancing yaitu ASTINET dedicated dengan internet backup, peneliti melakukan beberapa tahapan yang berpedoman pada pendekatan PPDIOO yaitu prepare (persiapan), plan (perencanaan), Desain (desain), Implement(implementasi), operate(operate) dan optimize(optimasi) (Setiyani, 2018). Pendekatan PPDIOO merupakan pendekatan yang khusus digunakan dalam pengembangan LAN dan WLAN (Solikin, 2017).

Pendekatan ini berfungsi untuk memberikan kemudahan kepada peneliti dalam mengaplikasikan teknik load balancing sehingga proses penggabungan dua layanan internet tesebut dapat berjalan dengan optimal sesuai dengan kebutuhan penggunanya.

Dalam implementasi teknik load balancing, peneliti menggunakan metode static route with address list yang memberikan kemudahan dalam membagi jaringan dengan topologi sederhana, dan tidak ada disconnection pada client yang disebabkan perpindahan getway karena load balancing. Berikut adalah gambar atau logika dari metode static route with address list yang akan diterapkan: 


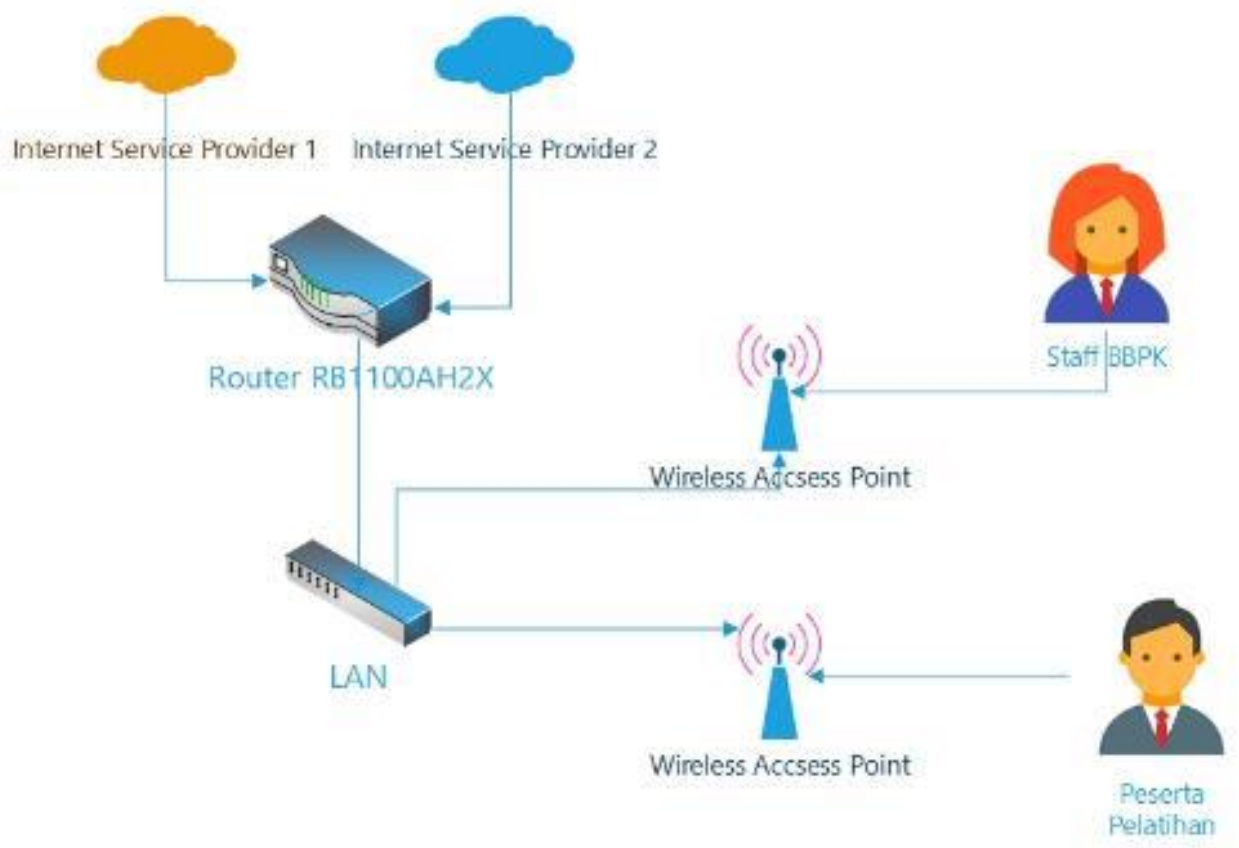

Gambar 1. Logica static route with address list

Selain pemilihan metode, pada implementasi load balancing ini peneliti memilih tipe load balancing menggunakan hardware load balancing yaitu router mikrotik RB1100AH2X. Penggunaan RB1100AH2X sebagai hardware load balancing ini karena perangkat ini memiliki harga yang murah dan memiliki kualitas serta tipe mikrotik ini sudah level 6 dengan port gigabite.

\section{HASIL DAN PEMBAHASAN}

Berikut adalah hasil dan pembahasan implementasi load balancing pada BBPK Ciloto:

\section{A. Prepare}

Untuk mengimplementasikan load balancing peneliti melakukan persiapan dengan melakukan analisis terhadap sumber daya yang tersedia di BBPK Ciloto. Analisis yang dilakukan adalah analisis terhadap ISP yang digunakan di BBPK ciloto dan hardware yang digunakannya. Berdasarkan hasil analisis berikut adalah ISP dan hardware yang digunakan di BBPK Ciloto :

Tabel 1. Analisis Infrastruktur dan layanan

\begin{tabular}{|c|c|c|}
\hline No & $\begin{array}{l}\text { Infrastruktur dan } \\
\text { lavanan }\end{array}$ & Analsisi \\
\hline 1 & $\begin{array}{l}\text { Internet primary } \\
\text { Astinet dedicated } 30 \\
\text { Mbps }\end{array}$ & Mendukung \\
\hline 2 & $\begin{array}{l}\text { Internet backup } \\
\text { Astinet Lite } 100 \mathrm{Mbps}\end{array}$ & Mendukung \\
\hline 3 & $\begin{array}{l}\text { router mikrotik } \\
\text { RB1100AH2X }\end{array}$ & Mendukung \\
\hline
\end{tabular}

Berikut adalah hasil analisis arsitektur jaringan internet yang ada di BBPK Ciloto: 


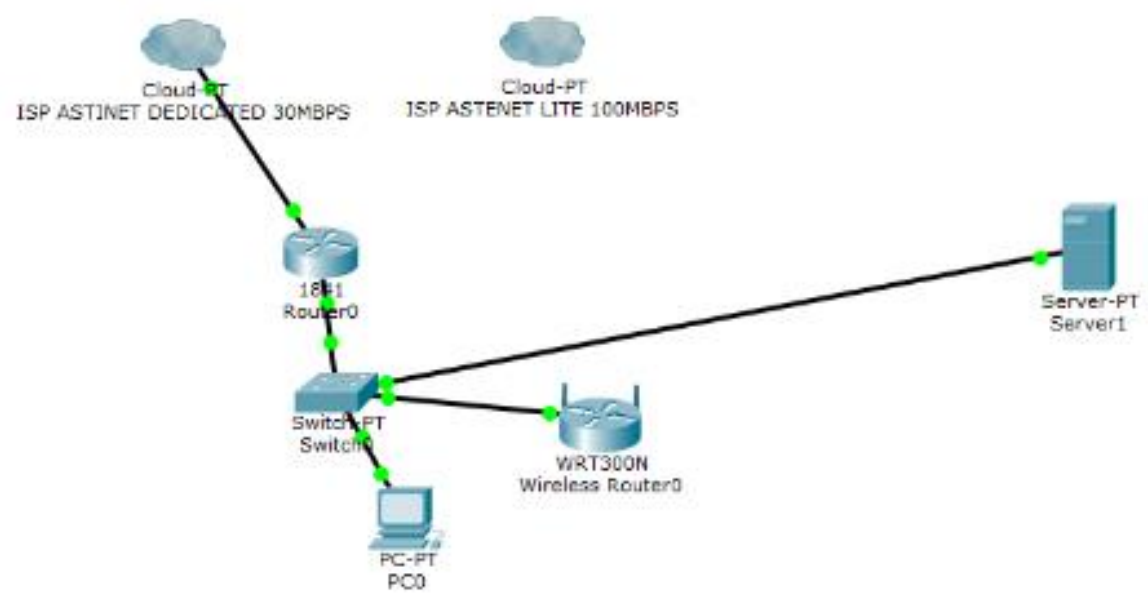

Gambar 2 . Analisis desain arsitektur jaringan internet yang ada di BBPK Ciloto

Gambaran dari hasil analisis diatas memperlihatkan bahwa dua ISP tidak tergabung dalam satu router sehingga beban pada jaringan tidak dapat dibagi secara seimbang.

B.

Plan

Perencanaan yang dalam mengimplementasikan load balancing pada jaringan internet di BBPK Ciloto dilakukan dengan menyusun penjadwalan terhadap kegiatan implementasia. Berikut adalah jadwal kegiatan implementasi load balancing di BBPK Ciloto :

Tabel 2. Jadwal kegiatan implementasi load balancing jaringan internet

\begin{tabular}{ccc}
\hline No & Kegiatan & Waktu \\
1 & Konfigurasi Load & 1 Hari \\
2 & $\begin{array}{c}\text { Balancing } \\
\text { Test } \\
\text { Implementation }\end{array}$ & 1 \\
&
\end{tabular}

\section{Desain}

Pada tahapan desain ini peneliti melakukan perancangan desain arsitektur jaringan internet yang mengaplikasikan load balancing. Berikut adalah desain arsitektur jaringan internet yang akan di aplikasikan :

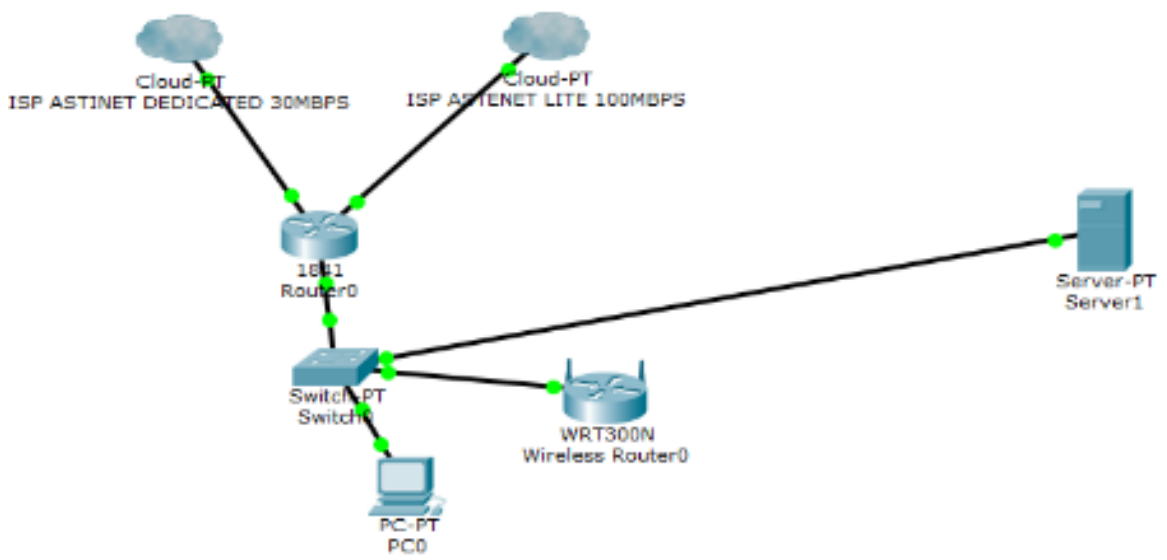

Gambar 3. Rancangan desain arsitektur jaringan internet dengan teknik load balancing. 
Desain gambar diatas memperlihatkan bahwa dengan router yang ada, peneliti melakukan penggabungan dua ISP ke dalam satu ruter dan dikonfigurasi untuk dialirkan secara seimbang sesuai beban kebutuhan LAN.

\section{Implement}

Pada tahapan implementasi ini dilakukan instalasi dan konfigurasi pada router untuk mengaplikasikan load balancing. Pertama - tama untuk melakukan konfigurasi load balancing dilakukan proses create IP pada router.

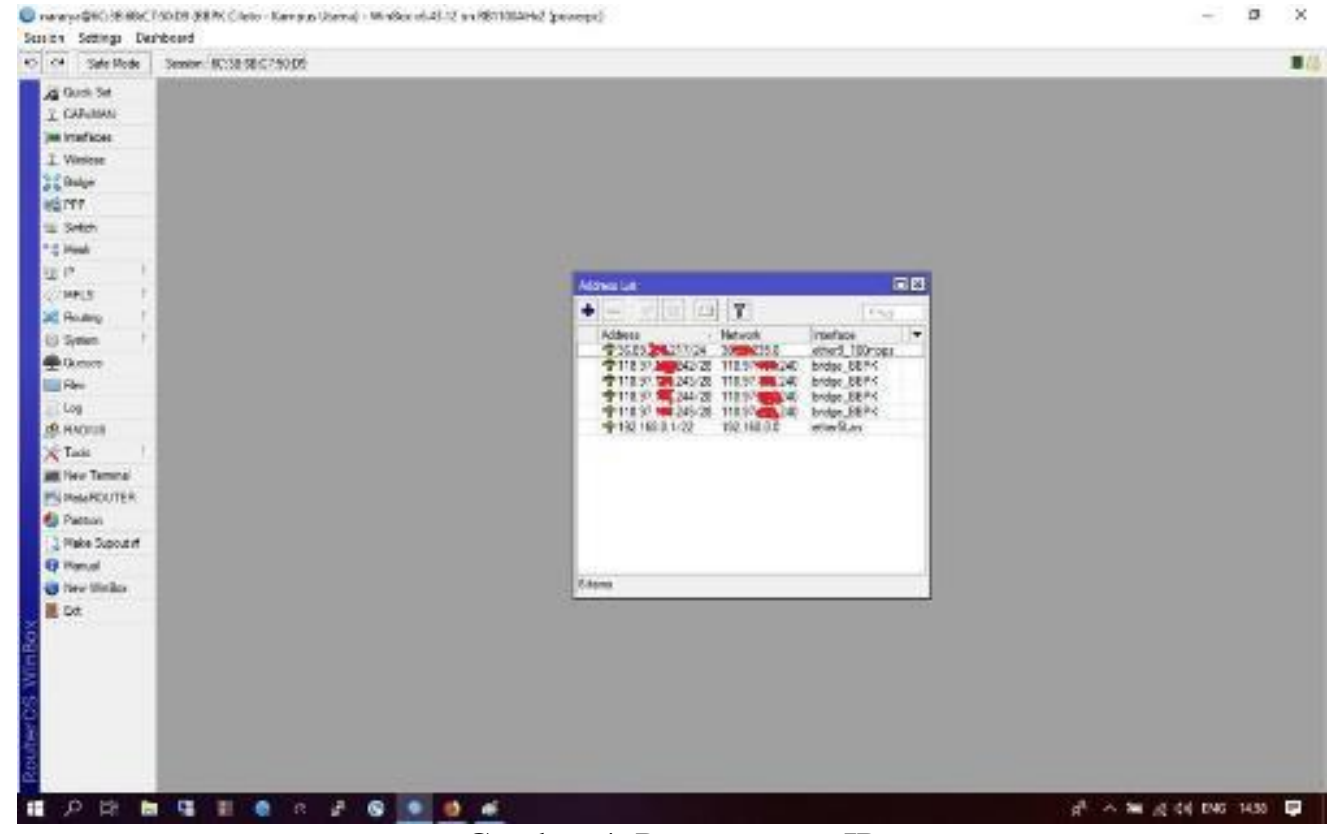

Gambar 4. Proses create IP

Setelah IP dibuat langkah selanjutnya adalah melakukan bridge yang berfungsi untuk menjembatani dan mengbuka IP dari yang diberikan ISP.

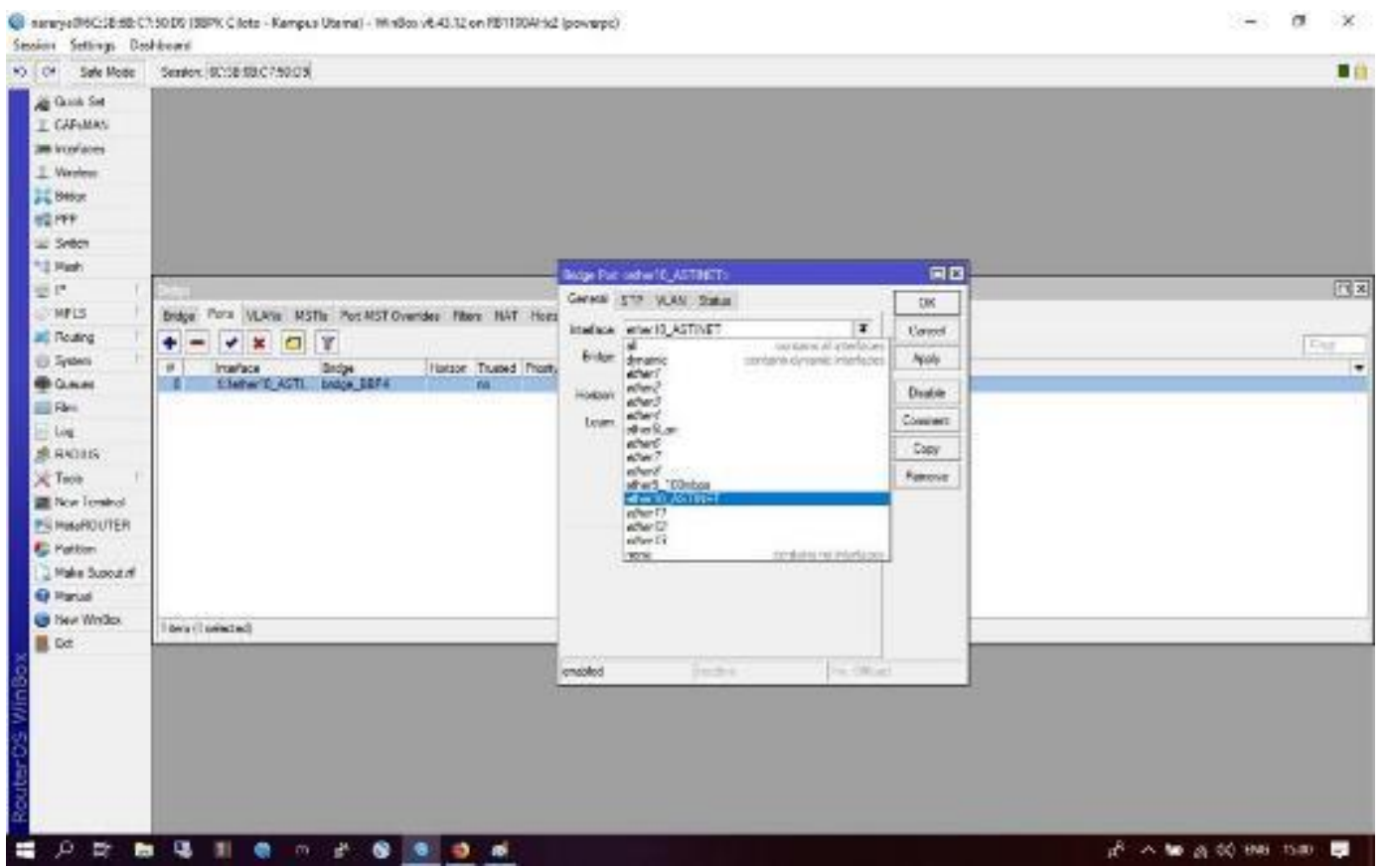

Gambar 5. Proses bridge 
Faktor Exacta 12(2); 112-121, 2019

p-ISSN: 1979-276X

e- ISSN: 2502-339X

DOI : 10.30998/faktorexacta.v12i2.3668

Langkah selanjutnya adalah create DNS.

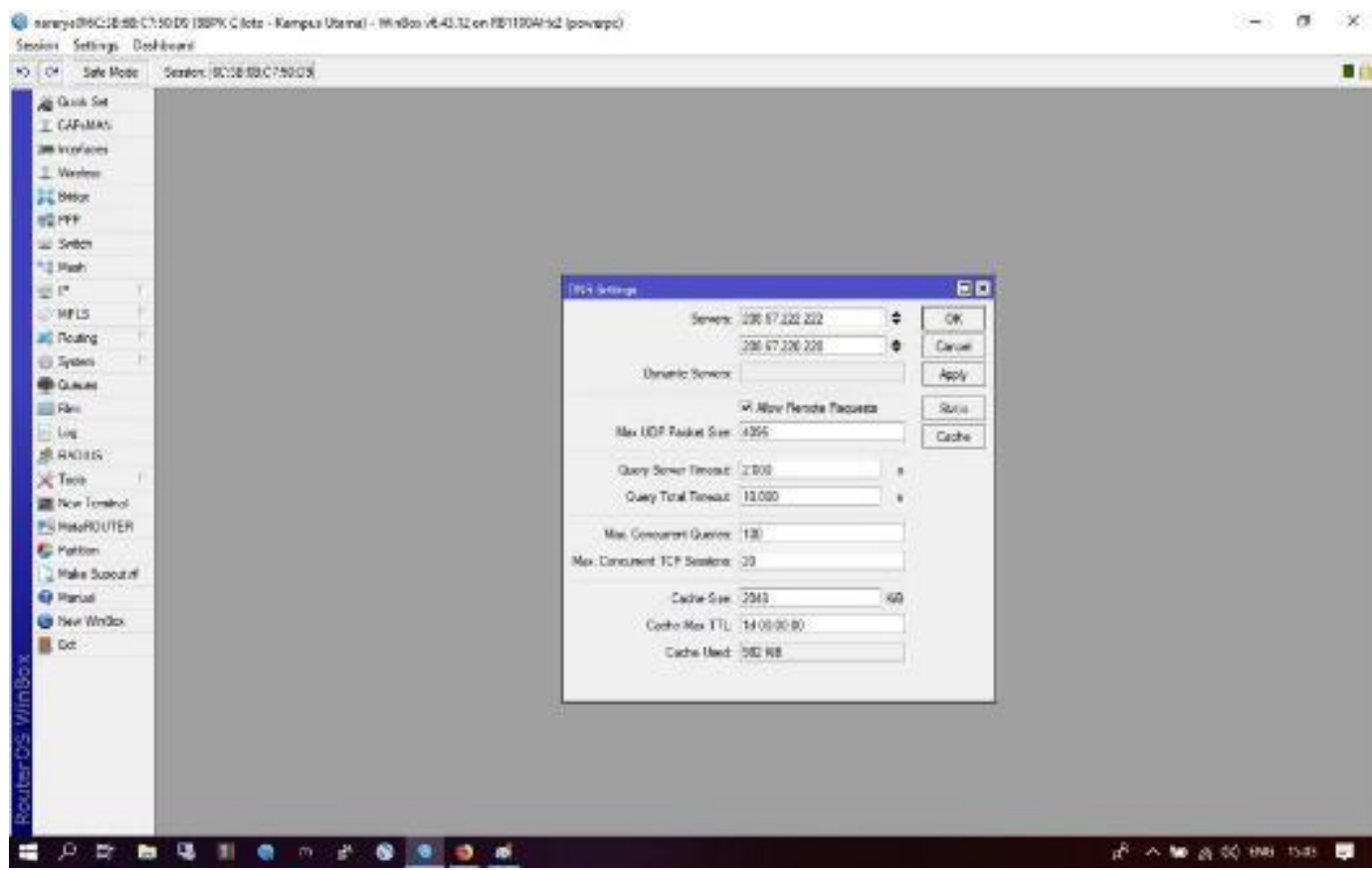

Gambar 6. Proses create DNS

Setelah DNS dibuat, langkah selanjutnya adalah mengatur firewall mangle untuk membuat aturan permission accsess dari LAN ke WAN:

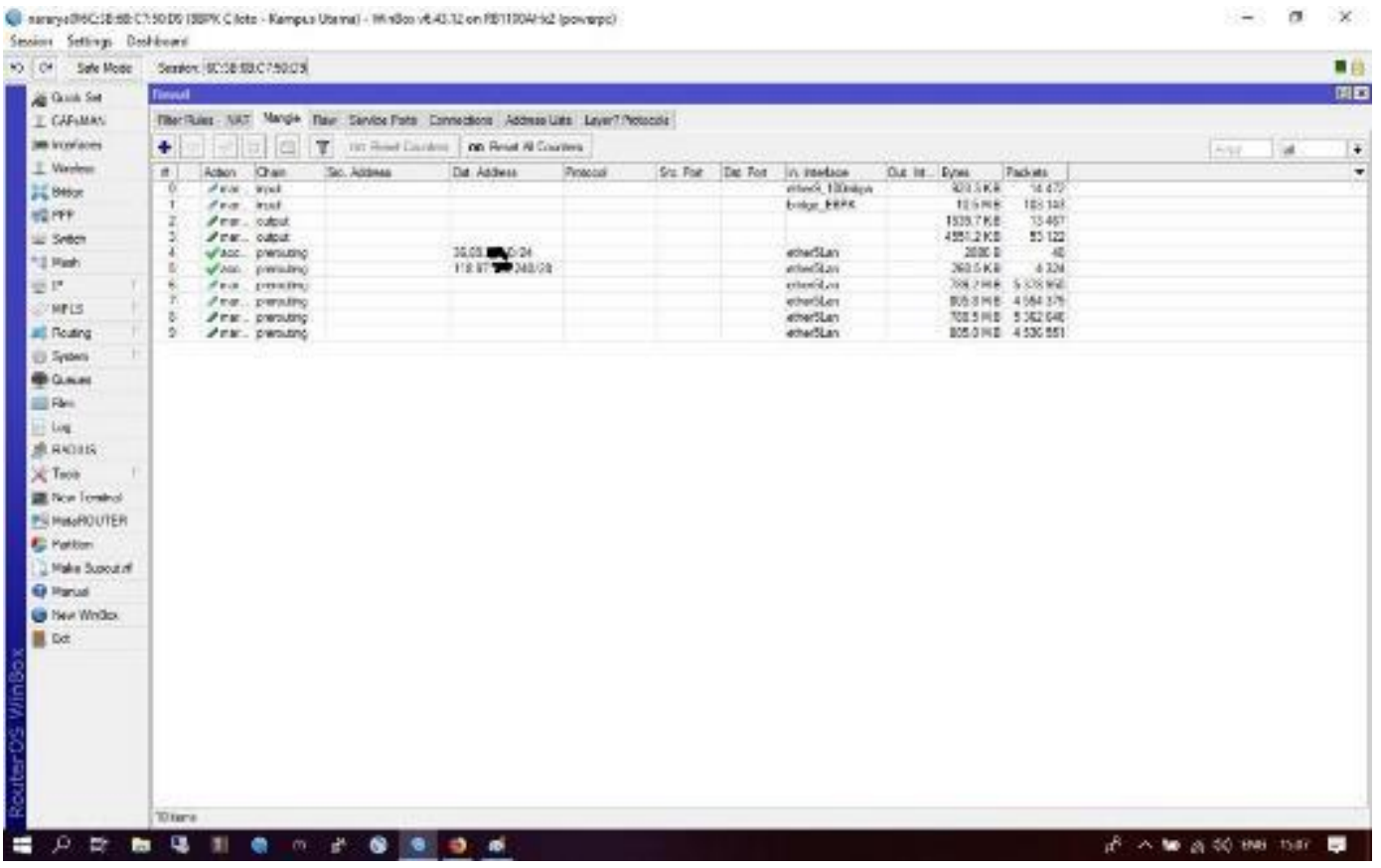

Gambar 7. Proses pengaturan firewall mangle. 


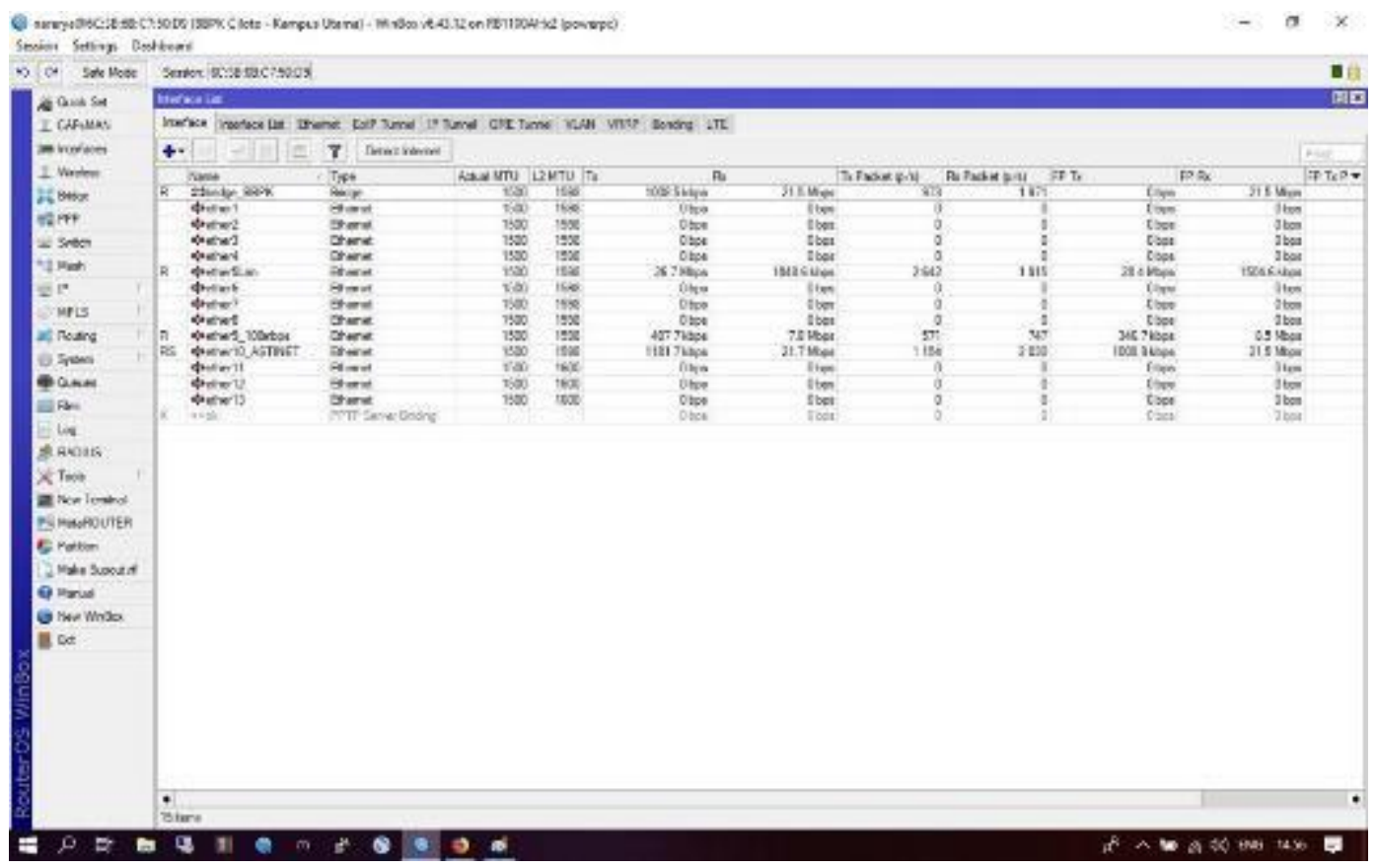

Gambar 8. Interface list

Langkah selanjutnya adalah membuat IP DHCP ke LAN:

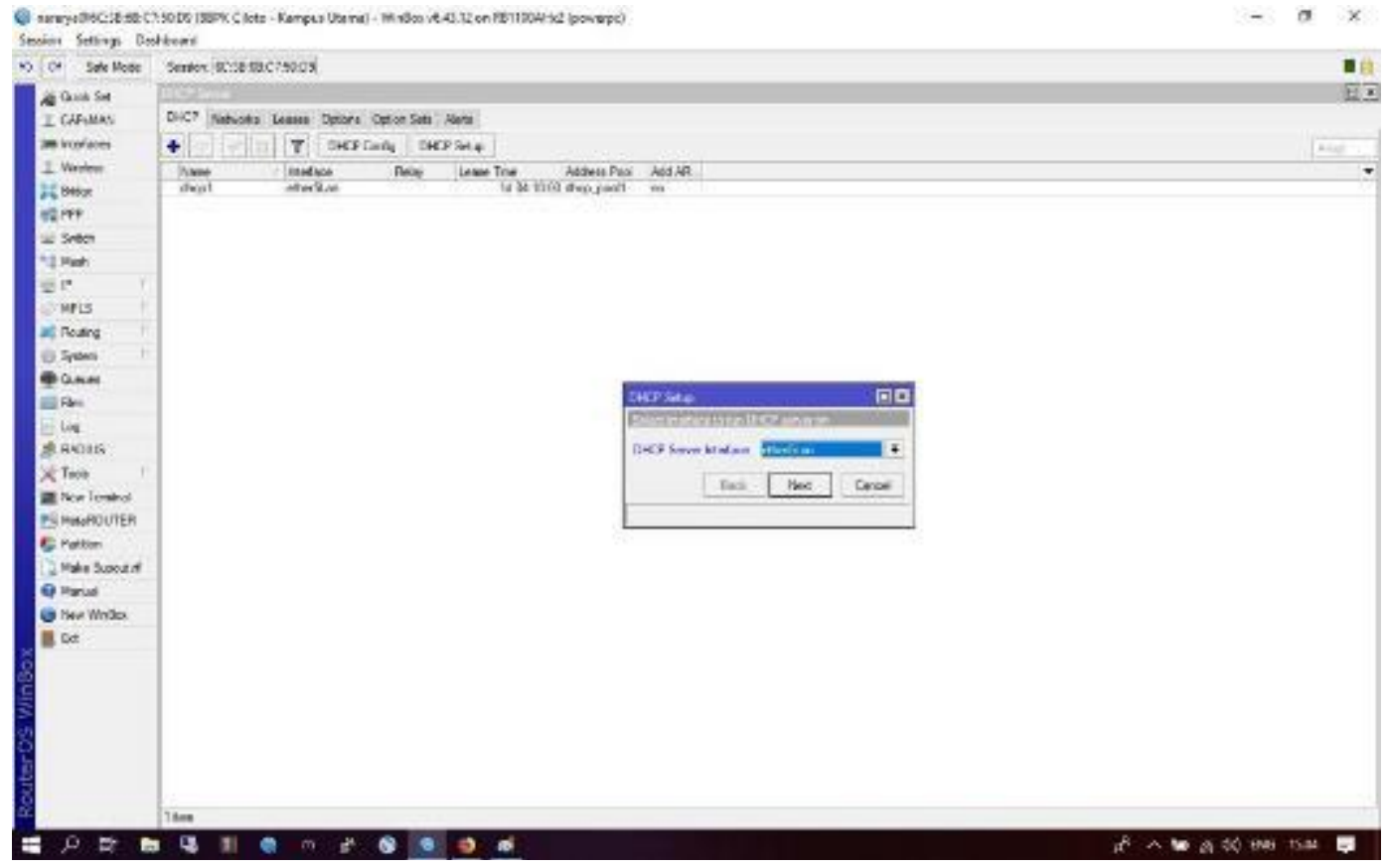

Gambar 9. Proses pembuatan DHCP

Setelah IP DHCP di create langkah selanjutnya adalah proses NAT (Network address translation) untuk membuka akses dari jaringan LAN ke jaringan internet/WAN. 
Faktor Exacta 12(2): 112-121, 2019

p-ISSN: 1979-276X

e- ISSN: 2502-339X

DOI : 10.30998/faktorexacta.v12i2.3668

Setiyani - Peningkatan Layanan Jaringan Internet....

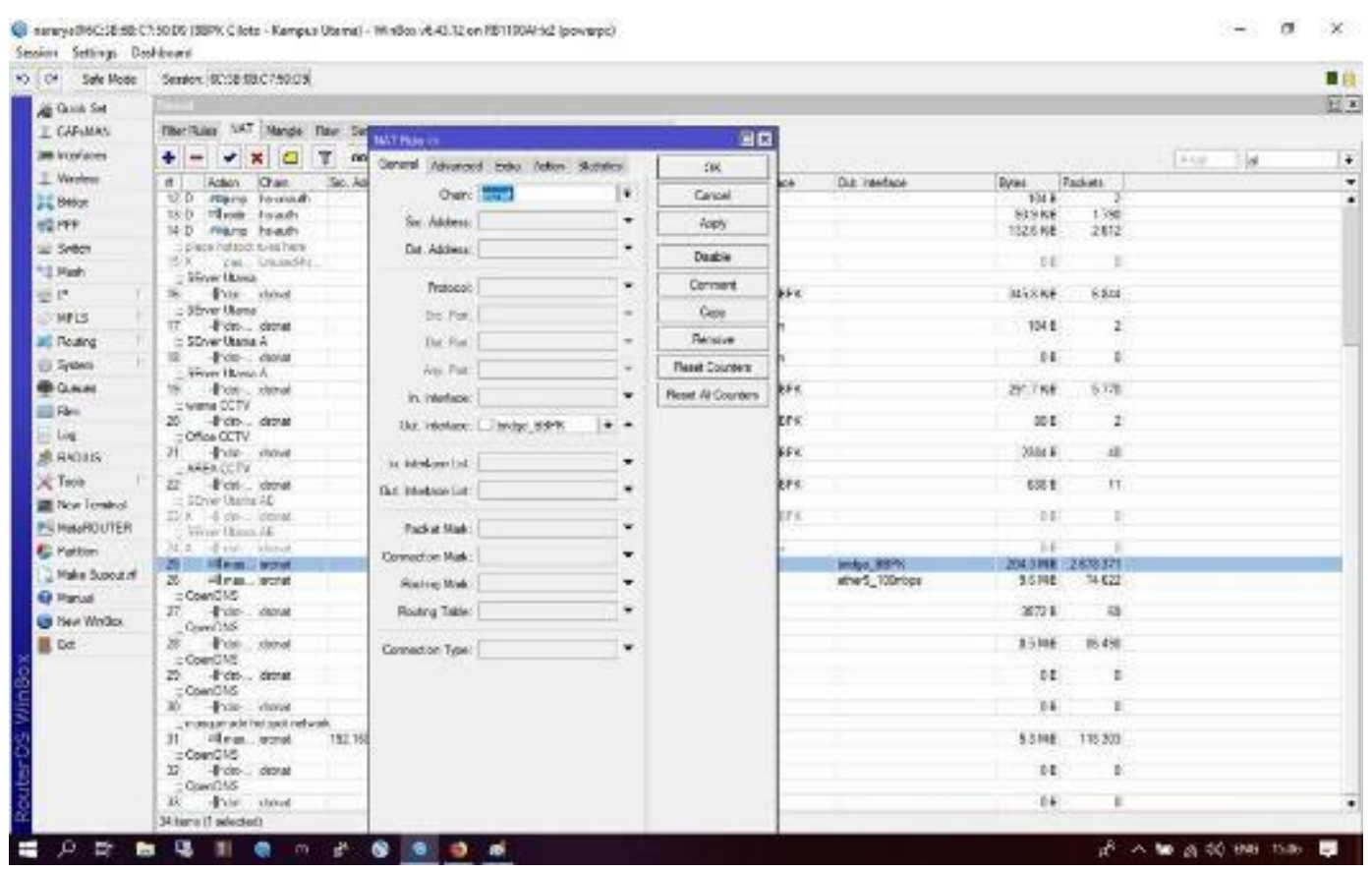

Gambar 10. Proses NAT

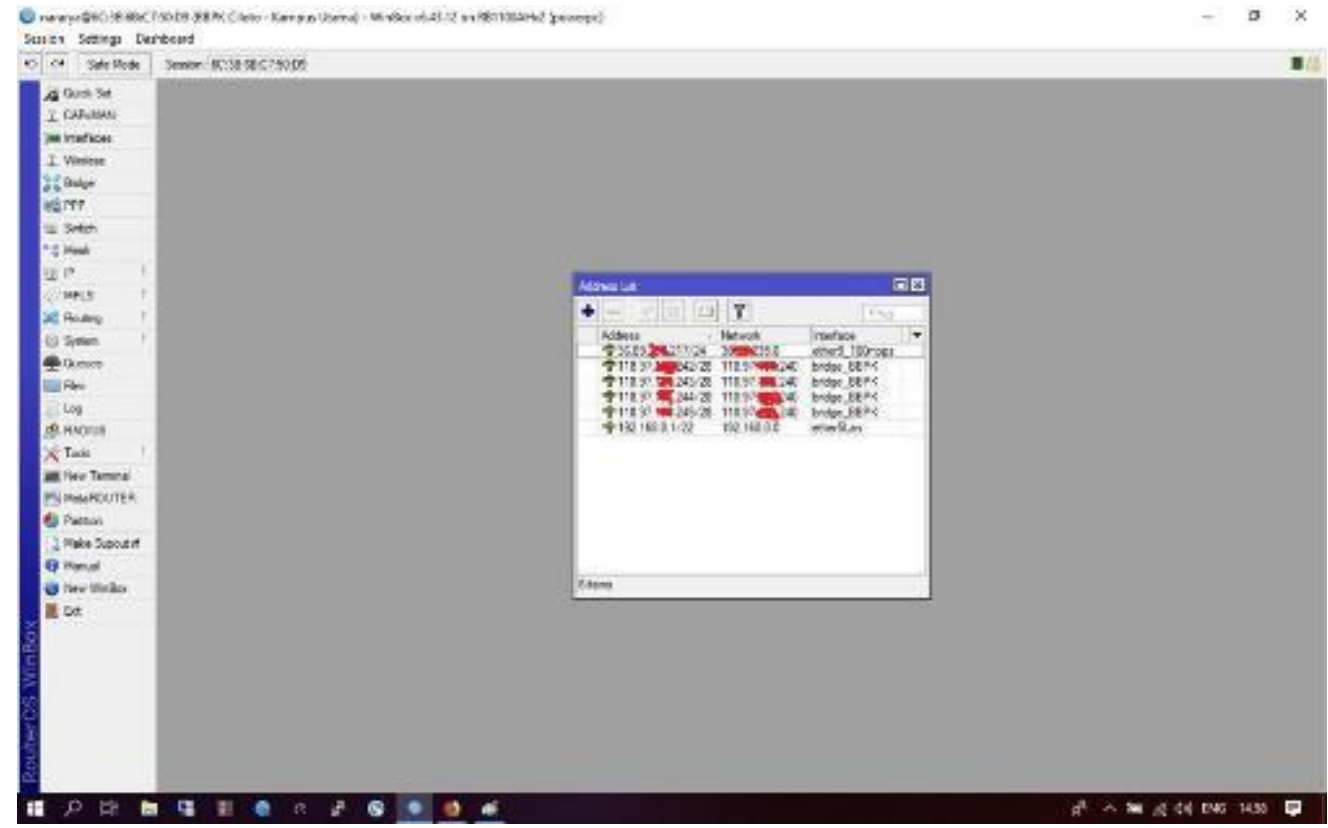

Gambar 11. Hasil address list

Langkah selanjutnya adalah mengatur hotspot setup yang digunakan untuk membuat jaringan hotspot untuk permisson acsess client. 


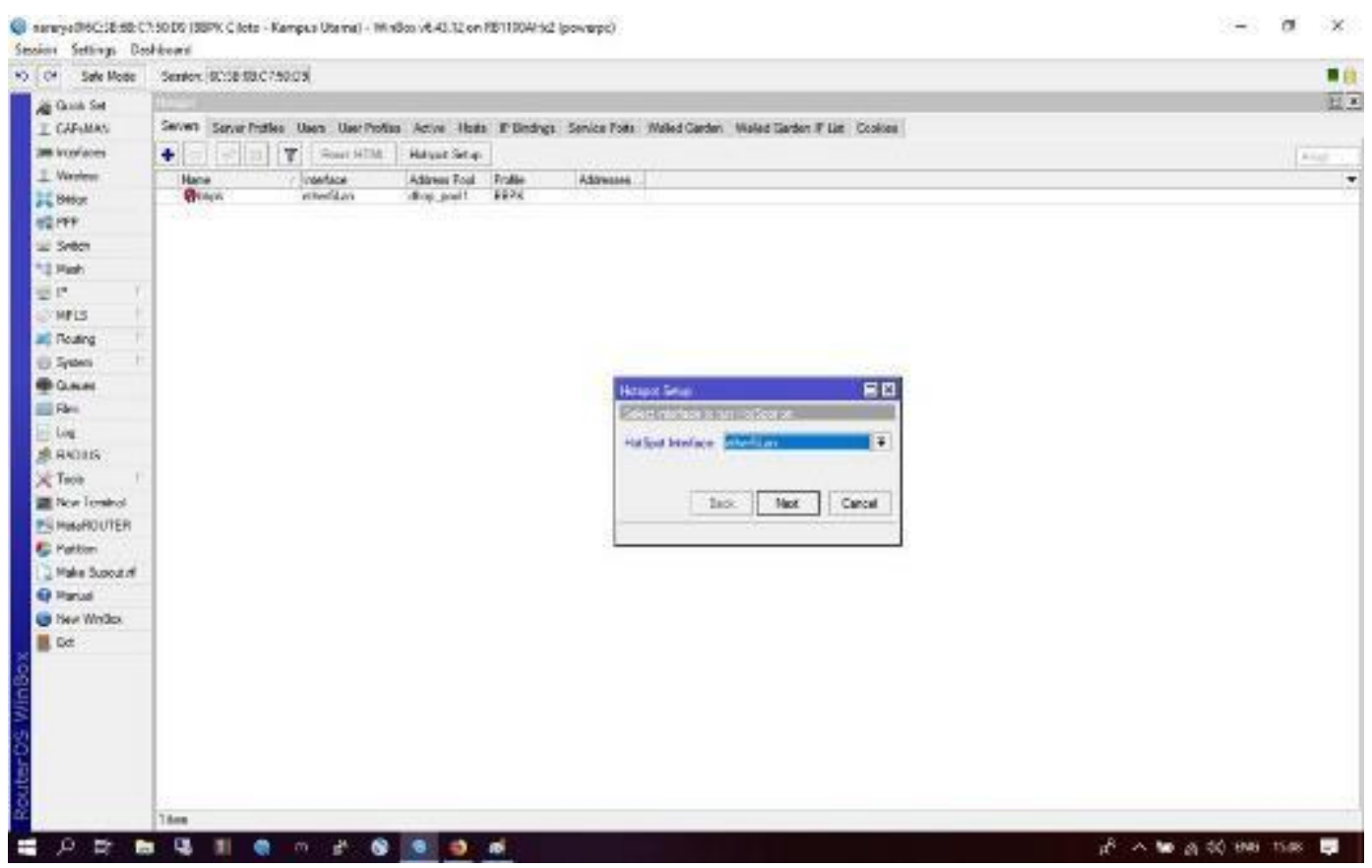

Gambar 12. Proses konfigurasi hotspot

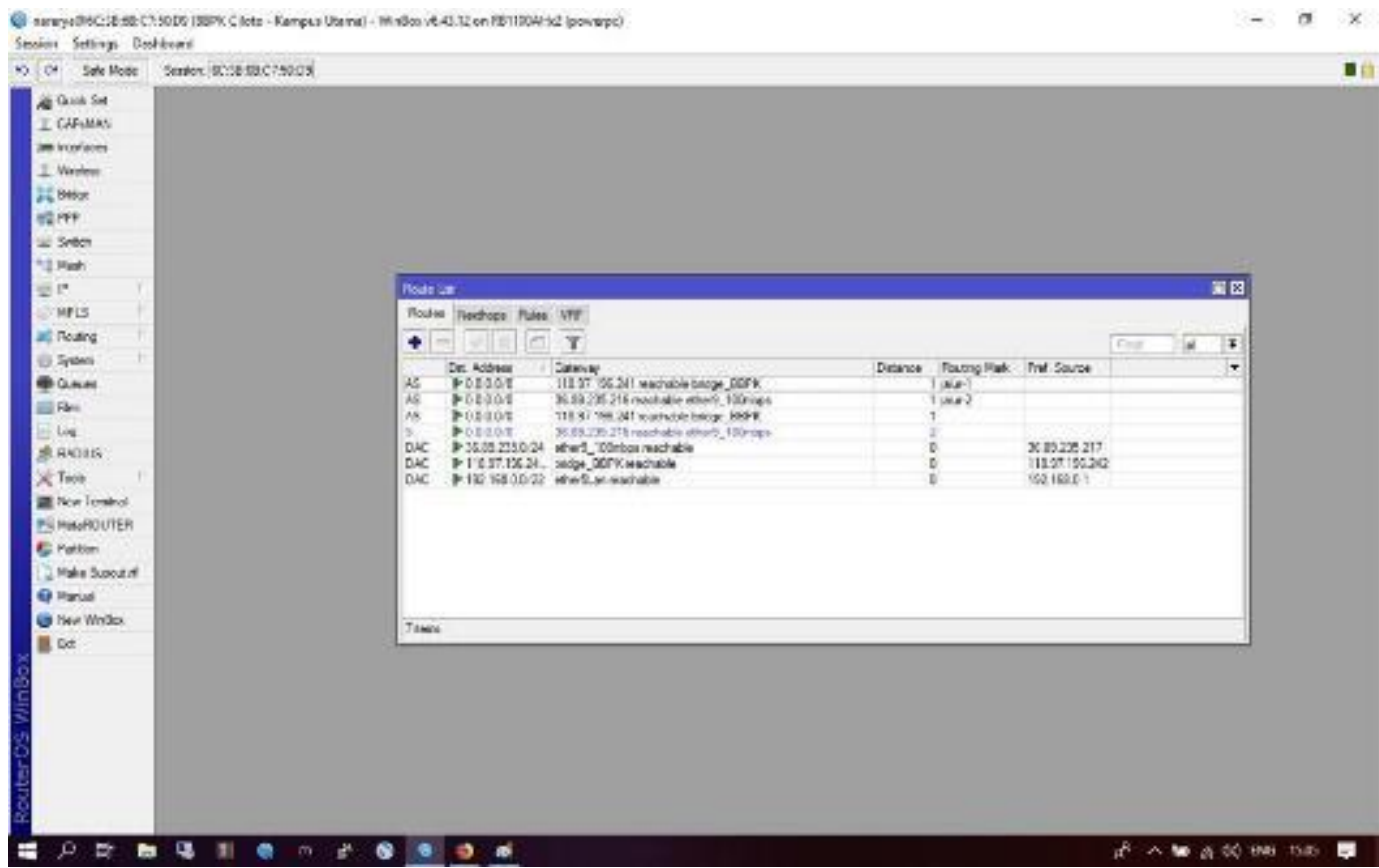

\section{E. Operate}

Gambar 13. Hasil proses load balancing

Pada tahapan operate ini dilakukan pengujian - pengujian terhadap trafic data yang berjalan di jaringan internet BBPK Ciloto . Pengujian dilakukan dengan melakukan speed test dengan beberapa jumlah user. Pengujian dilakukan sampai semua user mendapatakan kecepatan secara maksimal sesuai dengan kebutuhannya. 


\section{F. Optimize}

Untuk mengoptimalisasi dari implementasi load balancing pada jaringan internet BBPK Ciloto , peneliti membuat jadwal berkala untuk melakukan maintenance untuk menjaga stabilitas dari lalu lintas data yang terjadi di BBPK Ciloto.

Keterbaruan dari penelitian ini adalah peneliti dapat menggabungkan dua ISP dengan menggunakan hardware router yang memiliki fungsi disamping sebagai pengelola jaringan dapat juga sebagai perangkat load balancing. Metode load balancing menggunakan alat ini lebih mudah dalam instalasi dan lebih cepat dibanding menggunakan software load balancing.

\section{PENUTUP}

\section{Simpulan}

Setelah dilakukan implementasi load balancing pada BBPK Ciloto, terbukti bahwa load balancing dapat berfungsi sebagai backup internet dan load balancing mampu membagi beban lalu lintas data internet sehinggu penggunaan bandwith menjadi lebih efektif dan efisien. Perubahan yang terjadi setelah dilakukan load balancing dengan dua ISP ini adalah BBPK Ciloto tidak mengalami kekuarangan bandwith ketika penggunaan maksimal.

Walaupun implementasi load balancing ini berjalan dengan baik, namun pengawasan dari administrator jaringan tetap diperlukan, untuk menjaga stabilitas dari lalu lintas jaringan internet di BBPK Ciloto. Sehingga perlu dilakukan evaluasi secara berkala untuk mencatat kestabilan dari load balancing yang telah dilakukan.

\section{DAFTAR PUSTAKA}

Haris. (2013, Agustus 28). Mengenal 4 Metode Load Balancing. (Mebiso.com) Dipetik Januari 22, 2019, dari https://mebiso.com/mengenal-4-metode-load-balancing-untuk-jaringaninternet-anda/

IdCloudHost. (2015, Desember 27). Tipe Load Balancing. (PT Cloud Hosting Indonesia) Dipetik Januari 22, 2019, dari https://idcloudhost.com/mengenal-tipe-load-balancing-besertaperbandingannya/

IdCloudHost. (2017, September 18). ISP. (PT Cloud Hosting Indonesia) Dipetik Januari 22, 2019, dari https://idcloudhost.com/apa-itu-isp-internet-service-provider/

Muhammad Gustriana, S. (2016). Penerapan Teknik Load Balancing untuk Perancangan Jaringan VLAN pada Unit Pengelola Sistem Pengendalian Lalu Lintas DKI Jakarta. CKI On SPOT, Vol.9 (No.2), 89 - 98.

Setiyani, L. (2018). Research Method in Information Technology. Karawang: Jatayu Catra Internusa.

Solikin, I. (2017). Penerapan Metode PPDIOO Dalam Pengembangan LAN dan WAN. TEKNOMATIKA Vol 07. No. 01, 65 - 73. 